\title{
Feeding of Pellona flavipinnis (Clupeiformes, Pristigasteridae) in a Central Amazonian floodplain
}

\author{
Sandra S. Moreira-Hara ${ }^{1}$, Jansen A. S. Zuanon ${ }^{2} \&$ Sidineia A. Amadio ${ }^{2}$ \\ 1. Escola Superior Batista do Amazonas, Rua Leonor Telles, 278, Conj. Abílio Nery, Adrianópolis, Manaus, AM, Brazil. \\ (sandrasocorromoreira@yahoo.com.br) \\ 2. Instituto Nacional de Pesquisas da Amazônia, Av. André Araújo, 2936, Petrópolis, 69083-000 Manaus, AM, Brazil. (zuanon@inpa.gov.br; \\ amadio@inpa.gov.br)
}

\begin{abstract}
The feeding habits of Pellona flavipinnis (Valenciennes, 1836) at Catalão, a floodplain area on the Brazilian Central Amazon was studied. Data was obtained during three hydrological cycles, between September 1999 and September 2003. Diet composition, daily and seasonal variation in the feeding activity and the relationship between predator's size and its prey were analyzed. Almost $80 \%$ of the food consumed has autochthonous origin and diet was composed basically by insects and fish. Juvenile fish predominated in the stomach contents of all size classes but there was no significant relationship between predator's size and its prey. Pellona flavipinnis may be considered a carnivorous species which feeds mainly on juvenile (young-of-the-year) specimens of other fish. More intense feeding activity occurred at night and in the high water period.
\end{abstract}

KEYWORDS. Amazon basin, hydrological cycle, diet, carnivory, feeding activity.

RESUMO. Dieta de Pellona flavipinnis (Clupeiformes, Pristigasteridae) em planície alagada da Amazônia Central. Os hábitos alimentares de Pellona flavipinnis (Valenciennes, 1836) de uma área de várzea na Amazônia Central, Catalão, foram estudados. Foram utilizados dados referentes a três ciclos hidrológicos, entre setembro de 1999 e setembro de 2003. Foram analisados a dieta, a atividade alimentar diária e sazonal e a relação entre o comprimento da presa e o do predador. Cerca de $80 \%$ dos alimentos consumidos eram de origem autóctone e a dieta composta basicamente de insetos e peixes. Peixes juvenis predominaram nos conteúdos estomacais de exemplares de todas as classes de tamanho, mas não houve relação significativa entre o tamanho do predador e o das presas consumidas. Pellona flavipinnis pode ser considerada uma espécie carnívora que se alimenta principalmente de indivíduos juvenis de outras espécies de peixes. A atividade alimentar foi maior durante a noite e no período da cheia.

PALAVRAS-CHAVE. Bacia amazônica, ciclo hidrológico, dieta, carnivoria, atividade alimentar.

Pellona flavipinnis (Valenciennes, 1836) (Clupeiformes, Pristigasteridae) is a freshwater fish known in the Brazilian Amazon as apapá-branco. It has a wide geographic distribution in South America, including the Amazon, Parnaíba, Orinoco, Paraná/Prata basins and Guyana rivers (WhiteHEAD, 1985; PINNA \& Di DARIO, 2003). It reaches a moderate to large size, with at least $55 \mathrm{~cm}$ of standard length (PINNA \& Di DARIO, 2003), has pelagic habits and is supposed to be predominantly piscivorous (BRAga 1990; FERREIRA et al., 1998).

According to SAINT-PaUl et al. (2000), P. flavipinnis was the most abundant predator in a floodplain lake of Brazilian Amazon comprising the third highest biomass in controlled experimental fishing. At Catalão, a floodplain area near Manaus, P. flavipinnis was abundant in experimental fishing during low and high water seasons (Júlio D. do Vale, pers. comm.). In that area, a small human population of approximately 270 people performs a small scale commercial and subsistence fishing. To most of those people, fish represents the only source of animal protein, and the apapá-branco is part of their diet. The Catalão area has been subjected to intense human impacts such as deforestation and pollution. Habitat changes can modify fish diet (ABUNJANRA et al., 1999), possibly by affecting the food chain and the structure of fish communities. In this study we bring information on the feeding habits of $P$. flavipinnis, an abundant fish predator in a floodplain area in the Central Brazilian Amazon.

\section{MATERIAL AND METHODS}

The study took place in an area of the Amazon floodplain, named Catalão, at the confluence of the Amazonas River and Negro River, in Central Amazon, Brazil (Fig. 1). Despite the presence of Negro's black waters, the muddy, sediment-loaded waters of the Amazonas River predominate almost year round. It is a region of low-lying land, which, depending upon the hydrological period, it floods to form a large lake continuous with the rivers or forms an isolated lake.

The hydrological cycle for the studying site was defined according to BitTencourt \& AMADIO (2007), considering four hydrological periods: rising-water entering the river system and water levels increasing, from mid December to early March, between 20-26 m above sea level; high-water level equal to or above $26 \mathrm{~m}$ above sea level, from early March to late of July; recedingwater leaving the river system with water level decreasing, from late July to late October, between 26-20 m above sea level; low-water level equal to or below $20 \mathrm{~m}$ above sea level, from and October to mid December.

Fish were sampled monthly from September 1999 to September 2003, during three hydrological cycles using a set of 10 gillnets with mesh sizes ranging from 30 to 120 $\mathrm{mm}$ between opposite knots, measuring $10 \times 1.5-3.5 \mathrm{~m}$. Nets were set at the same site each time and left in the water for $24 \mathrm{~h}$, with fish being removed every 6 hours: 
dawn (6:00 am.), morning (12:00 am.), dusk (6:00 pm.) and night (12:00 pm.).

Fish were placed in coolers with ice and transported to the laboratory immediately, in order to minimize bias due to food digestion that may occur between capture and processing. In the laboratory fish were measured (standard length - Ls, in $\mathrm{mm}$ ), weighed ( $\mathrm{g}$ ) and digestive tract removed for analysis. A total of 63 specimens were taken for detailed analysis of the diet. Vouchers have been deposited in the Fish Collection of the Instituto Nacional de Pesquisas da Amazônia (INPA 31.403).

Feeding activity of the 63 dissected specimens was evaluated by means of a visual estimative of their stomach's degree of fullness (HAHN et al., 1999): zero (empty); one (up to $25 \%$ full); two (between 25 and $75 \%$ full) and three (stomach completely full). The digestive tract of specimens with food in the stomach was removed, placed in $5 \%$ formalin and later rinsed in water and preserved in ethanol $70 \%$. The intestine length of the specimens was measured $(\mathrm{mm})$ to calculate the Intestinal Coefficient: $\mathrm{IC}=\mathrm{Ls} / \mathrm{Li}$ (ZAVALACAmIN, 1996), where Ls = fish standard length $(\mathrm{mm}) ; \mathrm{Li}$ $=$ intestine length $(\mathrm{mm})$.

The stomach contents were analyzed under a stereomicroscope and food items were identified to the most precise taxonomic level and classified according to its origin: autochthonous or allochthonous. The relative importance of these categories in the fish's diet was verified using Alimentary Index, based on the frequency of occurrence of a food item among individuals and its relative volume (Hyslop, 1980): $\mathrm{A}_{i} \mathrm{I}=\mathrm{F}_{i} \mathrm{~V}_{i} / \Sigma\left(\mathrm{F}_{i} \mathrm{~V}_{i}\right)$ (KAWAKAMI \& VAzzoler, 1980), where $\mathrm{A}_{i} \mathrm{I}=$ alimentary index; $\mathrm{F}_{i}=$ frequency of occurrence of item $i$ (number of stomachs with item $i$, relative to total number of stomachs containing food); $\mathrm{V}_{i}=$ relative volume of item $i$ in an individual's stomach.

Possible seasonal differences in feeding activity were evaluated by means of Analysis of Variance (ANOVA, $\mathrm{p}<0.05$ ). Therefore, values of relative volume were transformed by its square root plus 0.5 so zero values

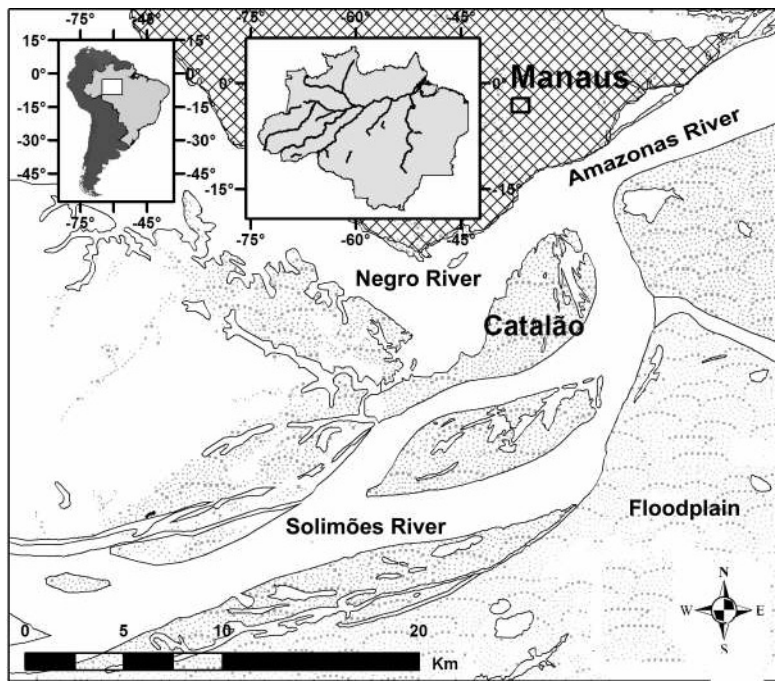

Figure 1. Map of the Catalão region, Central Amazon, Brazil. were eliminated (ZAR, 1996). Among food categories only those items which had AI values higher than 0.01 and occurred in at least three different hydrological periods were included in the analysis.

Prey fishes found in the stomach content were counted and measured (Ls - mm). The relationship between predator and prey fish size was tested by linear regression analysis. Daily and seasonal feeding activity were analyzed using the proportion of stomachs with and without food after transformed by its square root plus 0.5 , followed by an ANOVA analysis $(\mathrm{p}<0.05)$. The feeding activity of $P$. flavipinnis was also evaluated using the mean values of stomach fullness by the application of Kruskal-Wallis non-parametric analysis of variance ( $\mathrm{p}<$ 0.05; ZAR, 1996).

\section{RESULTS}

The specimens of $P$. flavipinnis captured ranged from 112 to $276 \mathrm{~mm}(160 \pm 1 \mathrm{~mm})$ in standard length and from 19 to $392 \mathrm{~g}(67 \pm 2 \mathrm{~g})$ in weight. The sac-like stomach of $P$. flavipinnis is subdivided in two chambers being proportionally long when compared to intestine length. It has thick walls with several internal folds, with numerous pyloric ceca $(50 \pm 1 ; n=9)$ in its anterior portion. The whole gut is positioned almost straight (not convoluted) inside the abdominal cavity, and is smaller than the fish's standard length (mean IC $=0.50 \pm 0.03$ $\mathrm{mm} ; \mathrm{n}=12$ ).

There were 29 food items identified in the stomach content of $P$. flavipinnis with about $83 \%$ being autochthonous, mainly fish and insects. Food items were classified into nine food categories (Fig. 2, Tab. I). The main preys were Ephemeroptera (nymphs), Hemiptera, Diptera larvae (mainly Chironomidae and Ceratopogonidae), Odonata, and Characiformes. Food items with less relative importance composed the category "others" and were not included in the analysis (Tab. I). Plant fragments were rarely found in the stomachs.

There was no obvious predominance of any particular prey in the diet of $P$. flavipinnis along the hydrological cycles, except for Ephemeroptera when river waters were receding (Fig. 2, Tab. II). Characiformes was the most important group of fish preyed upon, and the highest proportion of fish in the diet of P. flavipinnis was recorded when the river level was rising $(\mathrm{AI}=0.311$; Fig. 2; Tab. II). All prey fish were juvenile with 10 to $35 \mathrm{~mm}$ Ls. Nevertheless, there was not a significant relationship between the body size of $P$. flavipinnis and its prey ( $\mathrm{p}=$ $0.101 ; r^{2}=0.245$ ). More than one kind of prey was frequently found in the stomach of P. flavipinnis, sometimes in different degrees of digestion.

The feeding activity of $P$. flavipinnis, as indicated by the frequency (\%) of stomach with food and degree of stomach fullness, did not vary along the day cycle (ANOVA, $p=0.446$; Kruskal-Wallis, $p=0.735$ ) nor hydrological periods (ANOVA, $\mathrm{p}=0.726$; Kruskal-Wallis, $\mathrm{p}=0.126$ ); however, slightly higher percentages of stomachs with food were registered during high water period and between late afternoon and early evening (Tab. III). 


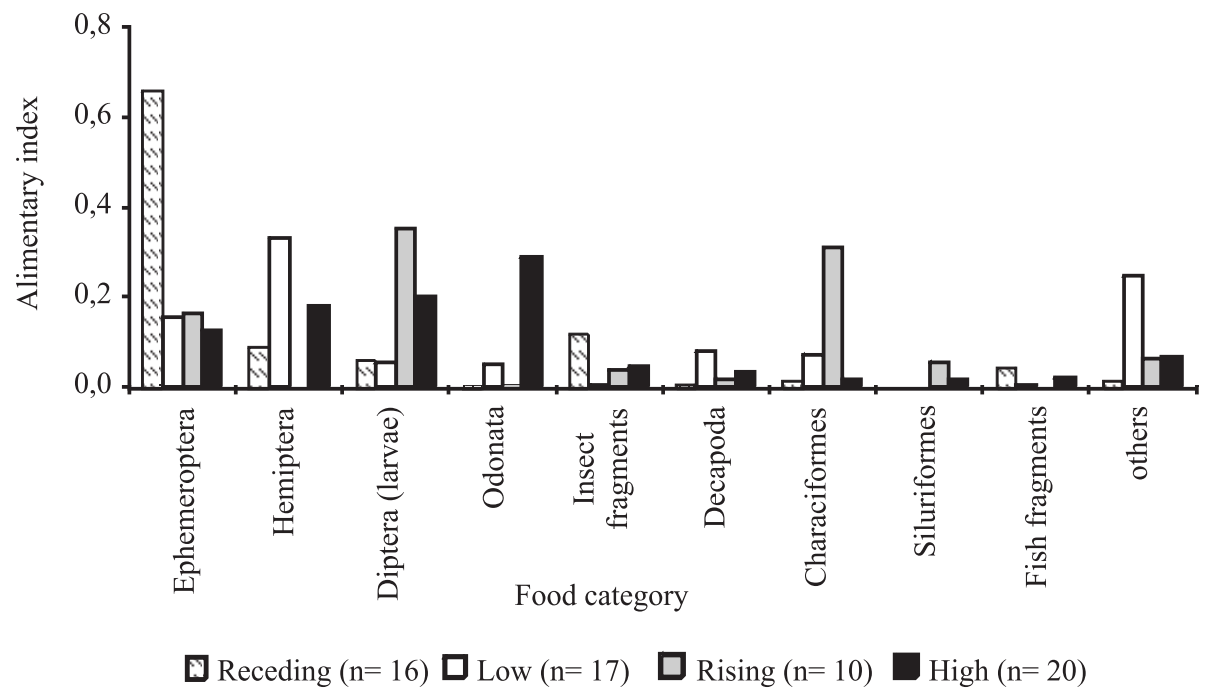

Figure 2. Alimentary Index of the food categories in the diet of Pellona flavipinnis (Valenciennes, 1836) captured at Catalão, Central Amazon, from September 1999 to September 2003, according to the hydrological period (n, number of specimens).

Table I. Alimentary Index values of food items in the diet of Pellona flavipinnis (Valenciennes, 1836) by hydrological period in the Catalão region, Central Amazon, from September 1999 to September 2003 (source: AL, allochthonous; AU, autochthonous; n, number of specimens).

\begin{tabular}{|c|c|c|c|c|c|}
\hline \multirow[b]{2}{*}{ Food items/categories } & \multirow[b]{2}{*}{ Source } & \multicolumn{4}{|c|}{ Hydrological period } \\
\hline & & Receding $(\mathrm{n}=16)$ & Low $(n=17)$ & Rising $(\mathrm{n}=10)$ & High $(\mathrm{n}=20)$ \\
\hline Ephemeroptera (nymphs) & $\mathrm{AU}$ & 0.6547 & 0.1555 & 0.1637 & 0.1237 \\
\hline \multicolumn{6}{|l|}{ Hemiptera } \\
\hline Notonectidae & AU & 0.0063 & 0.2899 & & 0.1788 \\
\hline Unidentified Family & & 0.0799 & 0.0429 & & 0.0004 \\
\hline \multicolumn{6}{|l|}{ Diptera } \\
\hline Chironomidae (larvae) & $\mathrm{AU}$ & 0.0580 & 0.0550 & 0.3471 & 0.2023 \\
\hline Caoboridae & AU & 0.0003 & 0.0612 & 0.0073 & \\
\hline Ceratopogonidae & $\mathrm{AU}$ & & 0.0006 & 0.0073 & 0.0002 \\
\hline Unidentified Family & & 0.0038 & 0.0057 & 0.0018 & 0.0575 \\
\hline \multicolumn{6}{|l|}{ Odonata } \\
\hline Libellulidae & AL & 0.0011 & 0.0460 & & 0.2837 \\
\hline Unidentified Family & $\mathrm{AU}$ & 0.0026 & 0.0031 & 0.0037 & 0.0049 \\
\hline Insect fragments & $\mathrm{AL} / \mathrm{AU}$ & 0.1137 & 0.0031 & 0.0365 & 0.0473 \\
\hline \multicolumn{6}{|l|}{ Decapoda } \\
\hline Acetes paraguayensis & $\mathrm{AU}$ & & & 0.0164 & \\
\hline Unidentified Family & $\mathrm{AU}$ & 0.0087 & 0.0778 & & 0.0347 \\
\hline \multicolumn{6}{|l|}{ Characiformes } \\
\hline Psectrogaster rutiloides & AU & & & & 0.0081 \\
\hline Triportheus spp. & AU & & & & 0.0088 \\
\hline Ctenobrycon hauxwellianus & AU & & & 0.0128 & 0.0006 \\
\hline Anodus sp. (larvae) & $\mathrm{AU}$ & & & 0.0110 & \\
\hline Unidentified Family & $\mathrm{AU}$ & 0.0142 & 0.0725 & 0.2868 & 0.0004 \\
\hline \multicolumn{6}{|l|}{ Siluriformes } \\
\hline Hypoptopomatinae & $\mathrm{AU}$ & & & 0.0197 & 0.0033 \\
\hline Auchenipteridae & $\mathrm{AU}$ & & & & 0.0146 \\
\hline Pimelodidae (larvae) & $\mathrm{AU}$ & & & 0.0329 & \\
\hline Fish remains & $\mathrm{AU}$ & 0.0450 & 0.0046 & & 0.0214 \\
\hline \multicolumn{6}{|l|}{ Others } \\
\hline Trichoptera & AU & 0.0014 & & & 0.0005 \\
\hline Coleoptera & $\mathrm{AL}$ & 0.0005 & 0.0015 & 0.0018 & 0.0007 \\
\hline Hymenoptera & $\mathrm{AL}$ & 0.0070 & & & \\
\hline Araneae & $\mathrm{AL}$ & & 0.0005 & & \\
\hline Ostracoda & $\mathrm{AU}$ & 0.0003 & 0.1596 & & \\
\hline Conchostraca & $\mathrm{AU}$ & & 0.0198 & 0.0365 & 0.0007 \\
\hline Cladocera & $\mathrm{AU}$ & 0.0023 & & & 0.0001 \\
\hline Seeds & $\mathrm{AU}$ & & 0.0006 & & 0.0005 \\
\hline Plant fragments & $\mathrm{AU} / \mathrm{AL}$ & & & 0.0146 & 0.0070 \\
\hline Total & & 1.000 & 1.000 & 1.000 & 1.000 \\
\hline
\end{tabular}


Table II. Mean relative volume of the main food categories on the diet of Pellona flavipinnis (Valenciennes, 1836) according to hydrological period in the Catalão region, Central Amazon, from September 1999 to September 2003. Values followed by the same letter at the same row do not differ statistically (Char, Characiformes; Deca, Decapoda; Dipt, Diptera (larvae); Ephe, Ephemeroptera; F, ANOVA test; Hemi, Hemiptera; n, number of specimens; $\mathrm{p}<0.05$ ).

\begin{tabular}{|c|c|c|c|c|c|c|c|}
\hline \multirow[b]{2}{*}{ Hydrological period } & \multicolumn{7}{|c|}{ Food categories } \\
\hline & Ephe & Hemi & Dipt & Deca & Char & $\mathrm{F}$ & $\mathrm{p}$ \\
\hline Receding $(n=14)$ & $36.0 \mathrm{a}$ & $11.3 \mathrm{ab}$ & $6.4 \mathrm{~b}$ & $3.9 \mathrm{~b}$ & $2.5 \mathrm{~b}$ & 4.28 & $0.004^{*}$ \\
\hline Low $(n=17)$ & 9.9 & 26.8 & 6.1 & 11.5 & 7.1 & 1.95 & 0.111 \\
\hline Rising $(n=10)$ & 11.2 & & 19.2 & 9.0 & 22.2 & 0.81 & 0.499 \\
\hline High $(\mathrm{n}=20)$ & 6.9 & 14.4 & 12.6 & 9.6 & 9.9 & 0.48 & 0.748 \\
\hline
\end{tabular}

Table III. Relative frequency (\%) of stomachs with food and degree of stomach fullness (DSF) of Pellona flavipinnis (Valenciennes, 1836), according to hydrological period and along the day cycle in the Catalão region, Central Amazon, from September 1999 to September 2003 (F, ANOVA test; H, Kruskall-Wallis test; n, number of specimens; $\mathrm{p}<0.05$ ).

\begin{tabular}{|c|c|c|c|c|c|c|c|c|}
\hline \multicolumn{9}{|c|}{ Mean relative frequency $(\%)$ of stomachs with food } \\
\hline & \multicolumn{4}{|c|}{ Hydrological period $(\mathrm{F}=0.447 ; \mathrm{p}=0.726)$} & \multicolumn{4}{|c|}{ Day cycle $(\mathrm{F}=0.906 ; \mathrm{p}=0.446)$} \\
\hline & Receding & Low & Rising & High & $6: 00 \mathrm{am}$ & 12:00 am & $6: 00 \mathrm{pm}$ & $12: 00 \mathrm{pm}$ \\
\hline$\%$ & 50.8 & 44.2 & 41.9 & 60.8 & 47.5 & 17.0 & 49.0 & 64.3 \\
\hline $\mathrm{n}$ & 111 & 197 & 144 & 73 & 86 & 24 & 46 & 81 \\
\hline \multicolumn{9}{|c|}{ Mean Degree of Stomach Fullness (DSF) } \\
\hline & \multicolumn{4}{|c|}{ Hydrological period $(\mathrm{H}=5.724 ; \mathrm{p}=0.126)$} & \multicolumn{4}{|c|}{ Day cycle $(\mathrm{H}=1.274 ; \mathrm{p}=0.735)$} \\
\hline & Receding & Low & Rising & High & $6: 00 \mathrm{am}$ & $12: 00 \mathrm{am}$ & $6: 00 \mathrm{pm}$ & $12: 00 \mathrm{pm}$ \\
\hline DSF & 1.92 & 1.43 & 1.56 & 1.83 & 1.70 & 1.33 & 1.67 & 1.76 \\
\hline $\mathrm{n}$ & 13 & 14 & 09 & 18 & 27 & 03 & 03 & 21 \\
\hline
\end{tabular}

\section{DISCUSSION}

The relationship between digestive tract morphology and diet has been demonstrated for fish (ZiHLER, 1982; VeriginA, 1990; BARBIERI et al., 1994). Carnivorous fishes usually have a large stomach with associated pyloric ceca, whereas in herbivores, the stomach is often small or almost absent (WoOTTON, 1990). The intestinal coefficient constitutes a diagnostic tool to verify the feeding habits of fish and, consequently, their role in the aquatic environment (BARBIERI et al., 1994). The intestinal coefficient found for P. flavipinnis (IC = $0.60 \pm 0.04)$ has an intermediate value among those registered for some piscivorous and carnivorous fishes as cited in BARBIERI et al. (1994) and WARD-CAMPBELL \& BeAmish (2005): Gymnotus carapo (Linnaeus, 1758) (Gymnotiformes, Gymnotidae) (IC $=0.40)$; Hoplias malabaricus (Bloch, 1794) (Characiformes, Erythrinidae) $(\mathrm{IC}=0.69)$; Rhamdia hilarii $(=$ R. quelen) (Quoy \& Gaimard in Freycinet, 1824) (Siluriformes, Heptapteridae) $(\mathrm{IC}=0.76) ;$ Channa limbata $(=$ C. lucius $)($ Cuvier, 1831) (Perciformes, Channidae) $(\mathrm{IC}=0.46 \pm 0.06)$. However, $P$. flavipinnis showed a lower intestinal coefficient when compared to omnivorous and herbivorous fishes (IC varying from 0.71 to 15.89 ; BARBIERI et al., 1994). Carnivorous fish usually have shorter intestines while omnivorous, herbivorous and detritivorous fishes show progressively longer intestine tracts (ZIHLER, 1982; WARDCampbell \& Beamish, 2005). Fishes that consume high nutritional food can process it faster and more efficiently with a shorter gut. Fishes whose diet include a high proportion of food items hard to digest, such as cellulose and lignin, have guts several times longer than their body length (Wootton, 1990; Delariva \& Agostinho, 2001).

The large proportion of autochthonous items consumed by $P$. flavipinnis reflects the high amount of fish and aquatic insects on its diet, which is probably related to the high productivity of the Central Amazonian floodplains (Morison et al., 2000). Pellona flavipinnis may be classified as a generalist carnivorous species that feeds mainly on fishes and aquatic insects, according to prey availability. BRAGA (1990) and FERREIRA et al. (1998) registered a piscivorous diet for this species from Tocantins River and mid course of the Amazonas River. On the other hand, Pouilly et al. (2004) studying the diet of P. flavipinnis from the floodplains of Mamoré River in Bolivia, found similar results when compared to this study.

The consumption of a large amount of Ephemeroptera in the receding water period may be related to the prey's life cycle and/or to the relative abundance of these invertebrates in the habitat occupied by $P$. flavipinnis.

A great number of insects associated to aquatic macrophyte roots appears in the Catalão with the decrease in water level. Although ephemeropterans reproduce year round in the Catalão region, its reproductive peak occurs in the early low water period when the waters are receding, and a large number of these insects are recorded in controlled samplings (Maria José N. Lopes, pers. comm.). Although not significant, $P$. flavipinnis showed a tendency to have a high proportion of stomach with food as well as a slightly high degree of stomach fullness during daytime and early night. Considering that juvenile fish and immature aquatic insects consumed by $P$. flavipinnis are usually found associated to the submerged roots of aquatic macrophytes, our results suggest that this fish is a visually oriented predator that hunts near the stands of aquatic macrophytes. However, the tendency of a higher feeding activity registered in the high water period may be related with a higher availability of larvae and juvenile fish in the floodplains during this time of the year (NICO \& TAPHORN, 1985). 
Furthermore, the higher feeding activity of $P$. flavipinnis in the high and receding water periods may be attributed to a higher energetic demand for the reproductive process (BRAGA 1990; ZwOLINSKI et al., 2001), which occurs along the low and rising water periods in the Catalão area (NEVES DOs SANTOS et al., 2008).

Prey size has been emphasized as one of the factors that may influence the food ingestion (AlmEIDA et al., 1997). However, in the case of P. flavipinnis, the consumption of small sized fishes indicates a feeding strategy based on the exploitation of the seasonal abundance of juvenile fish in the floodplains during the period of rising waters. During the early rainy season there is a very high abundance of larvae and juveniles of many fish species in the floodplain, notably of migratory fish which spawn in huge schools in those areas. The abundance of food and shelter for the fish larvae in the quick growing macrophyte stands are considered the main factors conditioning the spawn in highly productive floodplains (ARAuJo-Lima \& Goulding, 1998).

We conclude that Pellona flavipinnis from Catalão floodplains has a diet essentially composed by insects and juvenile (young-of-the-year) specimens of other fish species, and may be considered a carnivorous species. Its feeding activity is more intense at night and in the high water period.

Acknowledgments. The authors are grateful to INPA for financial and logistic support; V. R. Sobral for providing additional diet data; and to CAPES/CNPq for providing a scholarship to senior author.

\section{REFERENCES}

Abunjanra, F.; Russo, M. R. \& Hahn, N. S. 1999. Variações espaço-temporais na alimentação de Pimelodus ortomani (Siluriformes, Pimelodidae) no reservatório de Segredo e áreas adjacentes (PR). Acta Scientiarum 21(2):283-289.

Almeida, V. L. L.; Hahn, N. S. \& Vazzoler, A. E. A. M. 1997. Feeding patterns in five predatory fishes of the high Paraná River floodplain (PR, Brazil). Ecology of Freshwater Fish 6:23-133

Araujo-Lima, C. A. R. M. \& Goulding, M. 1998. Os frutos do tambaqui: ecologia, conservação e cultivo na Amazônia. Tefé-AM, Sociedade Civil Mamirauá. Brasília, CNPq. 186p.

Barbieri, G.; Peret, A. C. \& Verani, J. R. 1994. Notas sobre a adaptação do trato digestivo ao regime alimentar em espécies de peixes da região de São Carlos (SP). I. Quociente intestinal. Revista Brasileira de Biologia 54(1):63-69.

Bittencourt, M. M. \& Amadio, S. A. 2007. Proposta para identificação rápida dos períodos hidrológicos em áreas de várzea do Rio Solimões - Amazonas nas proximidades de Manaus. Acta Amazonica 37(2):307-312.

Braga, F. M. S. 1990. Aspectos da reprodução e alimentação de peixes comuns em um trecho do rio Tocantins entre Imperatriz e Estreito, Estados do Maranhão e Tocantins, Brasil. Revista Brasileira de Biologia 50(3):547-558.
Delariva, R. L. \& Agostinho, A. A. 2001. Relationship between morphology and diets of six neotropical loricariids. Journal of Fish Biology 58:832-847.

Ferreira, E. J. G.; Zuanon, J. A. S. \& Santos, G. M. 1998. Peixes Comerciais do Médio Amazonas, Região de Santarém/ PA. Brasília, IBAMA. 211p.

Hahn, N. S.; Loureiro, V. E. \& Delariva, R. L. 1999. Atividade alimentar de curvina Plagioscion squamosissimus (Heckel, 1840) (Perciformes, Sciaenidae) no Rio Paraná. Acta Scientiarum 21(3):309-314.

Hyslop, E. J. 1980. Stomach contents analysis: a review of methods and their application. Journal of Fish Biology 100:411-429.

Kawakami, E. \& Vazzoler, G. 1980. Método gráfico e estimativa de índice alimentar aplicado no estudo de alimentação de peixes. Boletim do Instituto Oceanográfico, São Paulo 29(2):205-207.

Morison, J. I. L.; Piedade, M. T. F.; Mueller, E.; Long, S. P.; Junk, W. J. \& Jones, M. B. 2000. Very high productivity of the $\mathrm{C}_{4}$ aquatic grass Echinochloa polystachya in the Amazon floodplain confirmed by net ecosystem $\mathrm{CO}_{2}$ flux measurements. Oecologia 125:400-411.

Neves dos Santos, R.; Ferreira, E. J. G. \& Amadio, S. A. 2008. Effect of seasonality and trophic group on energy acquisition in Amazonian fish. Ecology of Freshwater Fish 17:340348.

Nico, L. G. \& TAPHORN, D. C. 1985. Diet of Acestrorhynchus microlepis (Pisces: Characidae) in the low llanos of Venezuela. Copeia 3:794-796.

Pinna, M. C. C. \& Di Dario, F. 2003. Family Pristigasteridae. In: Reis, R. E.; Kullander, S. O. \& Ferraris JR., C. J. eds. Check List of the Freshwater Fishes of South and Central America (CLOFFSCA). Porto Alegre, Edipucrs. p.43-45.

Pouilly, M.; Yunoki, T.; Rosales, C. \& Torres, L. 2004. Trophic structure of fish assemblages from Mamoré River floodplain lakes (Bolivia). Ecology of Freshwater Fish 13:245-257.

Saint-Paul, U.; Zuanon, J.; Correa, M. A. V.; Garcia, M. \& Fabré, N. N. 2000. Fish communities in central Amazonian white and blackwater floodplains. Environmental Biology of Fishes 57:235-250.

Verigina, I. A. 1990. Basic adaptations of the digestive system in bony fishes as a function of diet. Voprosy ikhtiologii 30(6):897-907.

Ward-Campbell, B. M. S. \& Beamish, H. F. W. 2005. Ontogenetic changes in morphology and diet in the snakehead, Channa limbata, a predatory fish in western Thailand. Environmental Biology of Fishes 72:251-257.

WhiteheAD, P. J. P. 1985. FAO species catalogue. Vol. 7. Clupeoid fishes of the world (Suborder Clupeoidei). Parte 1. Chirocentridae, Clupeidae and Pristigasteridae. FAO Fisheries Synopsis 1(7):1-303.

Wootton, R. J. 1990. Ecology of teleost fishes. London, Chapman \& Hall. 404p.

ZAR, J. H. 1996. Biostatistical analysis. New Jersey, Prentice Hall. $662 \mathrm{p}$

Zavala-Camin, L. A. 1996. Introdução aos estudos sobre alimentação natural em peixes. Maringá, Nupélia. 129p.

ZIHLER, F. 1982. Gross morphology and configurations of digestive tracts of Cichlidae (Teleostei, Perciformes): phylogenic and functional significance. Netherlands Journal of Zoology 34(4):544-571.

Zwolinski, J.; Stratoudakis, Y. \& Soares, E. 2001. Intra-annual variation in the batch fecundity of sardine off Portugal. Journal of Fish Biology 58:1633-1645.

Recebido em julho de 2007. Aceito em novembro de 2008. ISSN 0073-4721

Artigo disponível em: www.scielo.br/isz 